\title{
Sampling strategies to estimate suspended sediment concentration for turbidimeter calibration
}

\author{
Leandro Dalbianco ${ }^{1}$, Rafael Ramon ${ }^{2}$, Claudia A. P. de Barros ${ }^{2}$, \\ Jean P. G. Minella ${ }^{3}$, Gustavo H. Merten ${ }^{4} \&$ Elizeu J. Didoné ${ }^{3}$ \\ ${ }^{1}$ Instituto Federal Farroupilha/Campus Jaguari. Jaguari, RS. E-mail: agro.dalbianco@gmail.com \\ ${ }^{2}$ Universidade Federal do Rio Grande do Sul/Departamento de Solos. Porto Alegre, RS. E-mail: rafaramon11@gmail.com; claudia.barros@ufrgs.br \\ (Corresponding author) \\ ${ }^{3}$ Universidade Federal de Santa Maria/Departamento de Solos. Santa Maria, RS. E-mail: jminella@gmail.com; didoneagroufsm@gmail.com \\ ${ }^{4}$ University of Minnesota Duluth/Department of Civil Engineering. Duluth, MN, USA. E-mail: mertengh@gmail.com
}

Key words:

turbidity

rainfall event

sampling

automatic sensors

\begin{abstract}
A B S T R A C T
The influx of sediments carried by rivers can be measured continuously using a turbidimeter through the indirect relationship between turbidity and suspended sediment concentration (SSC). However, this process is dependent on obtaining water samples with suspended sediments to calibrate the turbidimeter. Sampling can be carried out through different methods, resulting in errors and uncertainties in estimating the SSC. Four different possibilities for the composition of the calibration curve were tested in order to evaluate the effectiveness of the turbidimeter calibration for different sampling strategies. The study was conducted in 2012 and 2013 in two catchments in southern Brazil that had a strong sediment yield impact. The results indicate that sampling during rainfall events generate a significant and representative SSC for the turbidimeter calibration. The use of an integrating sampler for synthetic samples provides an effective calibration, but overestimates SSC compared to calibration from rainfall event sampling. The samples collected at fixed intervals - weekly and daily - generated an insufficient amount of data and are not representative of real sediment concentrations of the catchments.
\end{abstract}

\section{Palavras-chave:}

turbidez

eventos pluviométricos

amostragem

sensores automáticos

\section{Estratégias de amostragem para estimar a concentração de sedimentos em suspensão para a calibração do turbidímetro}

\section{R E S U M O}

O fluxo de sedimentos em rios pode ser medido continuamente com o uso de turbidímetro, pela relação indireta entre turbidez da água e concentração de sedimentos em suspensão (CSS). Entretanto, isso é dependente da obtenção de amostras com sedimentos em suspensão para a calibração do turbidímetro, a qual pode ser realizada de diferentes formas, originando erros e incertezas na estimativa da CSS. No intuito de avaliar a eficácia de diferentes estratégias de amostragem para a calibração do turbidímetro foram testadas quatro diferentes possibilidades para a composição da curva de calibração. O trabalho foi realizado em duas bacias hidrográficas no sul do Brasil com forte impacto na produção de sedimentos entre 2012 e 2013 . Os resultados indicam que a amostragem durante eventos gera uma quantidade significativa e representativa de valores de CSS para a calibração. O uso do amostrador integrador no tempo para a obtenção de amostras sintéticas permite uma boa estratégia de calibração, mas superestima os valores de CSS em relação à calibração com amostras de eventos. As amostras coletadas em intervalos fixos (semanais e diários) geram uma quantidade insuficiente de dados e não representativos das concentrações de sedimentos que ocorrem nas bacias. 


\section{INTRODUCTION}

Turbidimetry has been widely used for monitoring suspended solid discharges. It represents an additional and efficient option to overcome the limitations of traditional suspended sediment concentration (SSC) monitoring (Pavanelli \& Bigi, 2005). Turbidity is the transparency level of a solution that contains suspended and dissolved substances (Slaets et al., 2014) that causes light to be scattered instead of passing through the solution in a straight line. Thus, the higher the intensity of scattered light, the higher the turbidity level.

Turbidimeter calibration with samples of suspended sediment representing the location is important because the spectral responses obtained by turbidity sensors have no universal connection with the SSC (Mylvaganam \& Jakobsen, 2001). The relationship between turbidity and SSC depends on the different characteristics of suspended sediment, such as grain size (Merten et al., 2014), color, and mineralogy of the sediments (Rai \& Kumar, 2015). The particle size in transport varies with the hydraulic characteristics of the flow, erosive processes, geomorphological and lithological conditions of the catchment, and presence of vegetation (Slattery \& Burt, 1997; Lenzi \& Marchi, 2000).

The same material that is transported by the flow must be used for the turbidimeter calibration, and the samples obtained must have the same amplitude of the SSC that may occur in the flow, to avoid the extrapolation of the calibration curve. This is main obstacle in a successful calibration.

Different strategies have been employed to obtain SSC samples for turbidimeter calibration to overcome this problem (Minella et al., 2008), for example, use soil from the catchment, fine sediments collected from the deposits, and sediments transported during the rainfall events for calibration. According to Lewis (2002), sampling during various rainfall events is required due to differences that may exist among transported material from different rainfall events.

Different SSC sampling strategies were tested for turbidimeter calibration to demonstrate the differences in SSC estimation, depending on how calibration samples were acquired. Sampling was carried out based on rainfall events with fixed schedules (daily and weekly), as well as use of time-integrated samplers. While taking into consideration the impact on monitoring costs and estimate quality, the convenience of using a time-integrated sampler and daily and weekly samplings were evaluated in comparison with the samples collected during the rainfall events.

\section{Material AND Methods}

This study was conducted with turbidimeters monitoring gauge stations installed in the Conceição River ( $28^{\circ} 27^{\prime} 22^{\prime \prime}$ S; $53^{\circ} 58^{\prime} 24^{\prime \prime} \mathrm{W}$ ) and in the Guaporé River ( $28^{\circ} 54^{\prime} 41^{\prime \prime} \mathrm{S}$; $\left.51^{\circ} 57^{\prime} 10^{\prime \prime} \mathrm{W}\right)$ in the State of Rio Grande do Sul, southern Brazil (Figure 1), in 2012 and 2013.

The Conceição catchment has a drainage area of approximately $800 \mathrm{~km}^{2}$ and is characterized by dairy farming and grain production. The annual average precipitation in the

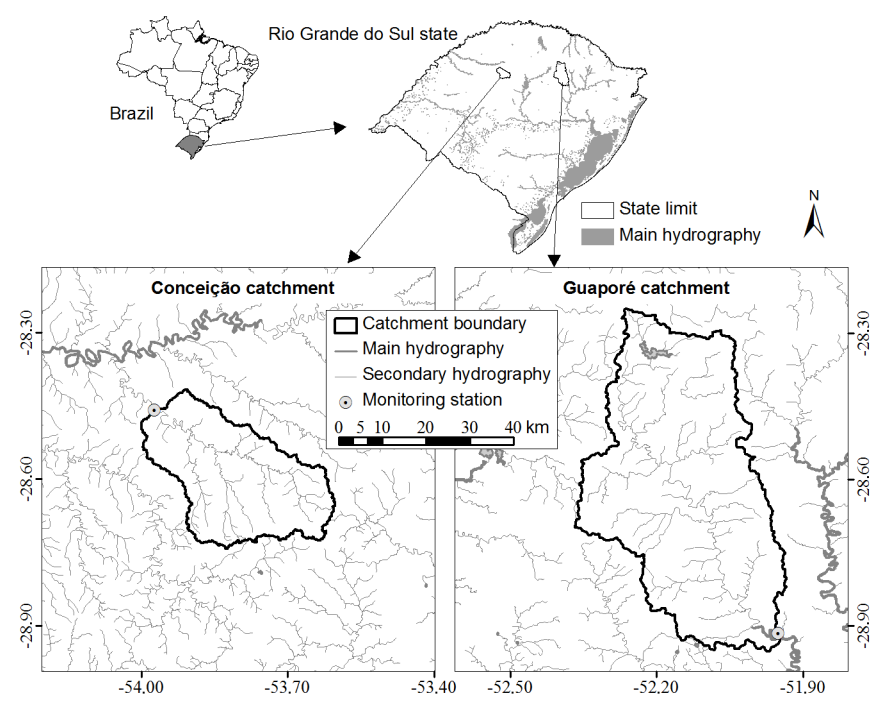

Source: TOPODATA (2011)

Figure 1. Location of the catchment monitored

region is 1,750 to $2,000 \mathrm{~mm}$. The topography of the region is characterized by low steepness (6-9\%) on top and middle part of the hillslope, and higher steepness (10-14\%) near the drainage channels. The soils of this catchment were classified as Ultisols, Alfisols and Oxisols. These soils are basaltic and well developed, thus exhibiting high amounts of clay and iron oxides. Therefore, the sediment produced is reddish and presents small average particle diameter. The average SSC of the Conceição River during base flow is $16 \mathrm{mg} \mathrm{L}^{-1}$, and $110 \mathrm{mg} \mathrm{L}^{-1}$ during the high flow. Despite the soil of the region is mainly managed in the no-tillage system, rills and gullies are found in cultivated areas and roads.

The Guaporé river catchment is located in the northeastern region of Rio Grande do Sul, with an area of approximately $2,000 \mathrm{~km}^{2}$, with heterogeneous landscape and soil management. The climate, according to the Köppen classification is Cfb, super humid subtropical, mesothermic, with cool summers, no dry season and severe frosts. The annual average precipitation is 1,400 to $2,000 \mathrm{~mm}$. The soils of this catchment were classified as Ultisols, Oxisols, Entisols and Luvisol. These soils are basaltic and very diverse due to the different landforms of the landscape. This diversity is also due to the varied particle sizes transported, since there are well developed soils with deep profile and young soils with shallow profile. Slopes and shallow soils, combined with non-use of soil conservation practices, promote erosion, generating significant amount of surface runoff and high soil loss rates in most part of this catchment. There are gentle slopes and deep soils in the upper third of the Guaporé catchment, but hillsides are long, and few grooves may form by water erosion in no-tillage areas.

Rain gauges, sensor depth and turbidimeter were used to monitor rainfalls, flow discharge and sediment flux, respectively. The mathematical relation between turbidity output in millivolt $(\mathrm{mV})$ and nephelometric turbidity units (NTU) was performed using a solution of polymers (polymer bead calibration solutions). The calibration with the solution used the points 0 (distilled water), 40, 100,400, 800, 1000 and 3000 NTU. The sensor was subjected to different concentrations 
of the standard solution (from the lowest to the highest concentration) and 20 signals emitted by the sensor (in $\mathrm{mV}$ ) were recorded, which were then converted into means for each concentration. A regression curve that converts $\mathrm{mV}$ into NTU was established. This analysis was used to the operation of the equipment and defining its linearity, repeatability and accuracy.

Turbidity (NTU) were correlated with the corresponding SSC (mg L $\left.{ }^{-1}\right)$, testing four mathematical relations:

(i) SSC-NTU using a time-integrated sampler to collect sediment samples;

(ii) SSC-NTU using suspended sediment samples collected during the rainfalls;

(iii) SSC-NTU using daily-suspended sediment samples;

(iv) SSC-NTU using weekly-suspended sediment samples.

\section{SSC-NTU using a time-integrated sampler to collect sediment samples}

Station time-integrated samplers were installed in each gauge station for sample collection. These sampler devices are easy to manufacture and are installed close to the river bed to collect sediments for a certain period of time, which can range from weeks to months, depending on the quantity of material transported in suspension. The construction was based on the sampler described by Phillips et al. (2000), using 7.5-cm diameter and 80-cm long PVC (polyvinyl polychloride) pipes, with caps with holes and 4-mm diameter pipes in both ends. The physical principle of operation is the small flow rate from the sampler favoring sediment settling, including clay particles. The samplers were submerged for a period of three months and then removed and taken to the laboratory to compose the different SSC.

The samples were dried in a forced-air circulation oven at $60{ }^{\circ} \mathrm{C}$, and then the organic material was oxidized with hydrogen peroxide and dispersed with $60 \mathrm{~mL}$ of sodium hydroxide solution at $1 \%$, followed by mechanical stirring for $12 \mathrm{~h}$. Finally, the solutions were placed in black plastic bottles to avoid light interference at the time of calibration. The concentrations used were $0,10,40,100,300,600,1000$, 1500 and $3000 \mathrm{mg} \mathrm{L}^{-1}$, and $20 \mathrm{NTU}$ turbidity readings (replicate measurements) were performed for each concentration, which generally had little or small standard deviation. These 20 readings were converted into a single mean NTU used in the NTU-SSC mathematical relation.

\section{SSC-NTU using suspended sediment samples collected during the rainfalls}

Suspension sediment samples were collected during the rainfalls close to the in-situ turbidimeter (Table 1) using

Table 1. Precipitated volume of rainfall events monitored in the Conceição and Guaporé catchments

\begin{tabular}{ccccc}
\hline \multicolumn{2}{c}{ Conceição catchment } & & \multicolumn{2}{c}{ Guaporé catchment } \\
\cline { 1 - 2 } \cline { 5 - 5 } Date & Precipitation $(\mathrm{mm})$ & & Date & Precipitation $(\mathrm{mm})$ \\
$07 / 21 / 11$ & $109.4^{*}$ & & $08 / 09 / 11$ & 100.5 \\
$10 / 01 / 11$ & 50.0 & & $08 / 29 / 11$ & $44.6^{*}$ \\
$10 / 08 / 11$ & 61.9 & & $07 / 06 / 12$ & 106.9 \\
$07 / 05 / 12$ & 72.0 & & & \\
\hline
\end{tabular}

* Occurrence of rainfall events with soil moisture near saturation due to prior rainfall a hand-held isokinetic sampler USDH-48. Samples were collected during the rising and falling hydrograph limb.

Suspended sediment samples were analysed in a laboratory using the evaporation method (Shreve \& Downs, 2005) to determine the SSC. The SSC obtained in each sample was correlated with the turbidity (NTU).

\section{SSC-NTU using daily-suspended sediment samples}

Daily suspended sediment samples were collected by local observer using an isokinetic sampler, similar to the USDH 48. The observer recorded date and time and identified the samples for subsequent correspondence with the turbidity data (NTU). The samples were properly stored and weekly sent to the laboratory to determine the SSC, as describe before. Daily SSC were correlated with the daily turbidity.

\section{SSC-NTU using weekly-suspended sediment}

Suspended sediment samples were collected every week using an isokinetic sampler, similar to the USDH 48 and sent to the laboratory to evaluate the SSC, as describe before. Thus, once a week a field campaign was carried out to sample the SSC.

\section{Data analysis}

In addition to the SSC analysis, the grain size of the samples was analysed to determine the average particle size of the samples collected with the SSC time-integrated sampler and during one rainfall event monitored in the two catchments. The average particle size ( $d_{50}$ in micrometers) was determined by the method of laser beam diffraction, using a laser granulometer. The method of particle size analysis also involved the burning of organic matter, chemical dispersion with sodium hydroxide $(\mathrm{NaOH})$, and mechanical dispersion for a period of $12 \mathrm{~h}$, before read by the laser granulometer (Beckman Coulter LS 13 320).

The data pairs (turbidity-SSC) were plotted and fitted to the most appropriate regression equation for the nature of the data in all sampling strategies. Differences between the sampling methods and possible interferences was also analysed.

\section{Results AND Discussion}

For samples collected daily, 191 SSC samples were collected in the Conceição and 171 SSC samples in the Guaporé catchment. In the case of weekly samples, 15 pairs of data in the Conceição catchment and 17 in the Guaporé catchment were used to develop the regression equation. It should be noted that between December 2011 and June 2012 there was a severe drought in the region without the occurrence of significant rainfall events.

Figure 2 shows the four mathematical regression between SSC-NTU. The results obtained in the calibration performed with samples of suspended sediment collected by timeintegrated samplers were fitted to a second-degree polynomial equation, with $\mathrm{R}^{2}=1.00$ (Conceição) and 0.98 (Guaporé) (Figure 2A). The advantage of using synthetic samples from the time-integrated sampler is to prepare high SSC that in many rainfall events are not possible to be reached.

The mathematical relation SSC-NTU using suspended sediment samples collected during rainfall events is illustrated 
- Conceição catchment data

- Guaporé catchment data

$\Lambda$.

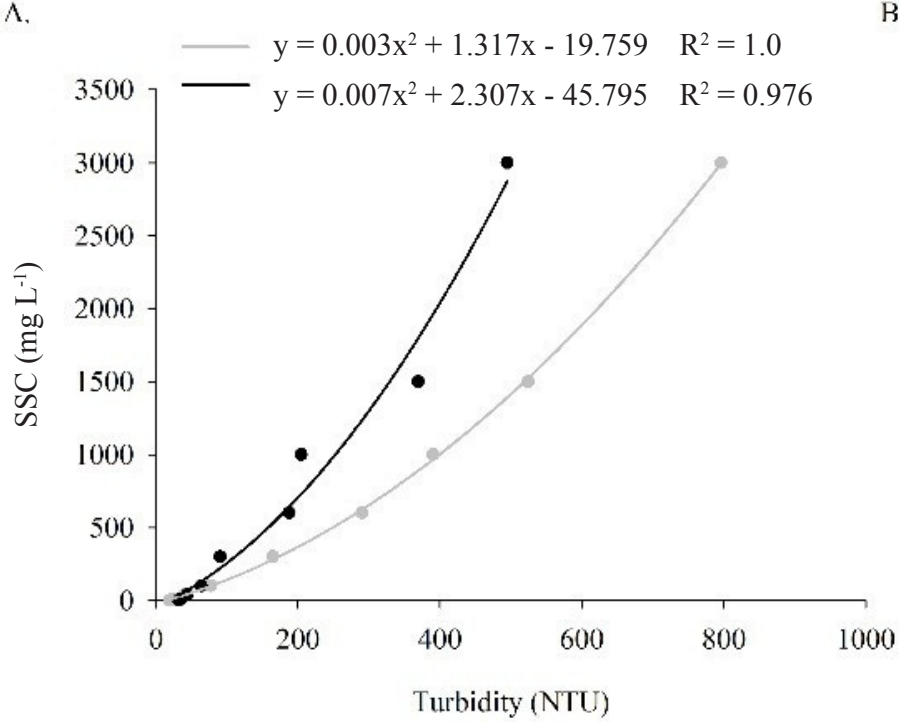

C.

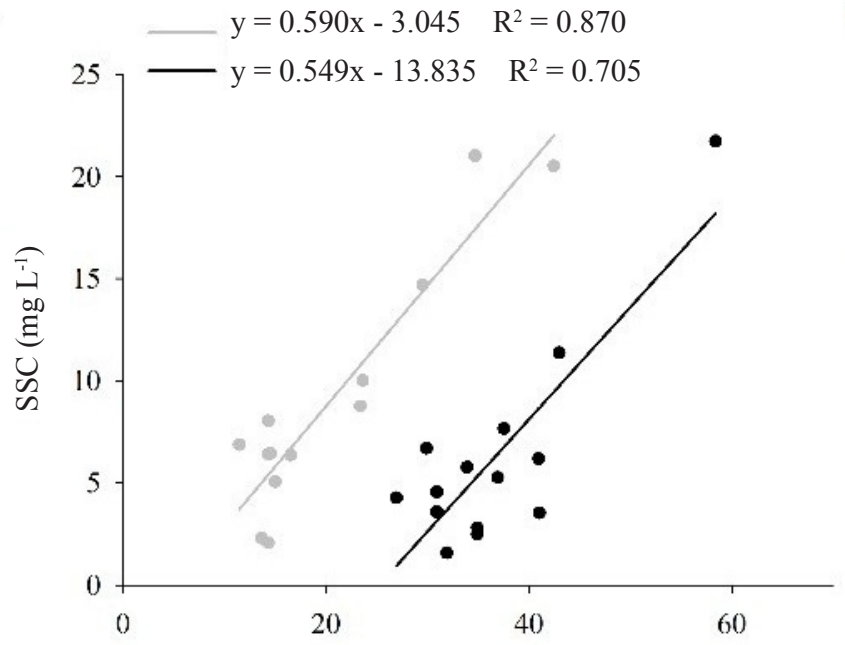

Turbidity (NIU)

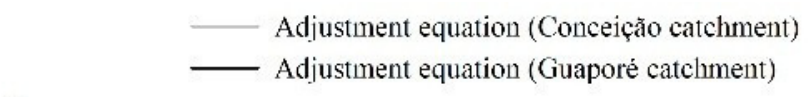

B.

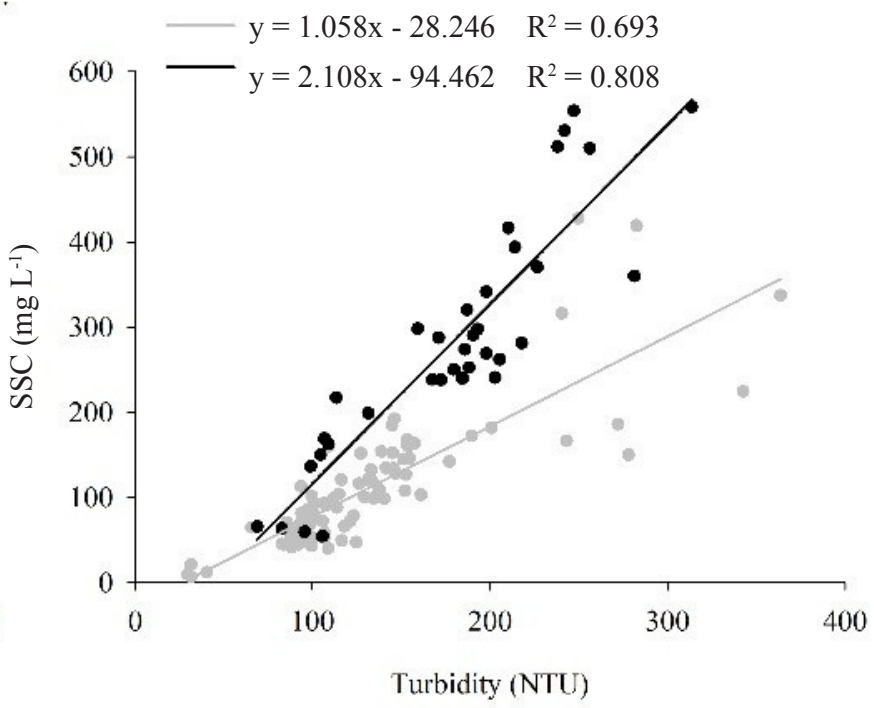

D.

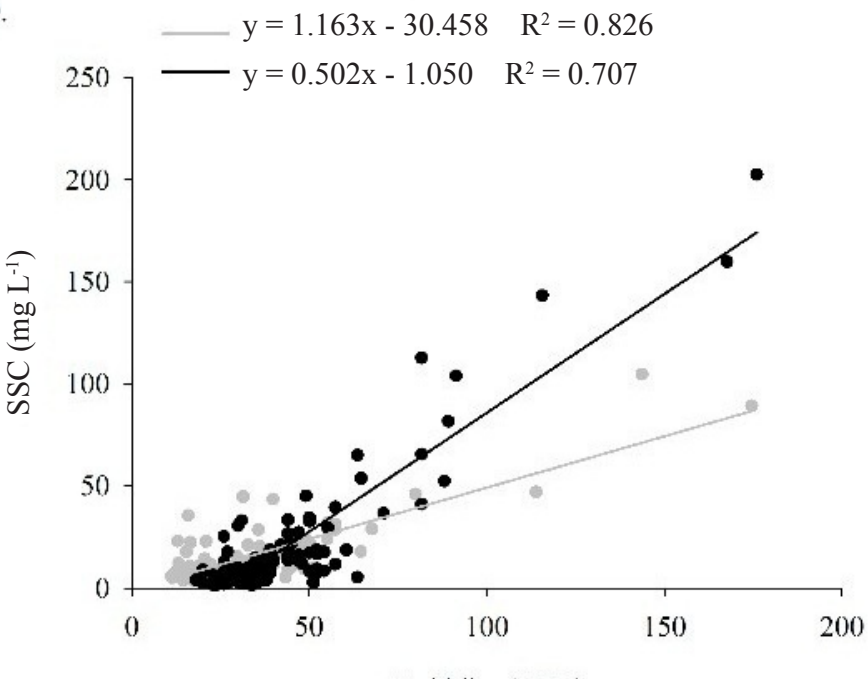

Turbidity (NIU)

Figure 2. Suspended sediment concentration - SSC Calibration curves for two experimental catchments under different sampling strategies: (A) with time integrated sampler, (B) collections in rainfall events, and weekly (C) and daily (D) collections

in Figure 2B. Despite large magnitude rainfall events were monitored, the maximum SSC did not exceed $600 \mathrm{mg} \mathrm{L}^{-1}$ in either location. The data of both turbidimeters were fitted to a linear equation. According to the Figure $2 \mathrm{C}$ and D, the SSC of the Conceição and Guaporé catchments was similar and the turbidity was greater in the Conceição. Despite the difference found in the particle size carried in suspension, it is unlikely that it affected the scattering of light emitted by the sensor (Rai \& Kumar, 2015). Other interfering factors not accounted for in this study may have caused the difference found, for example, color and mineralogy of the soil from each catchment. In the Conceição catchment, relief is gentle and wavy, and climate is warmer and humid, which favors the development of soils with deep profile, red soils with lots of clay minerals 1:1 (kaolinite) and iron oxides. These aspects should be explored in future researches.

The particle size $\left(\mathrm{d}_{50}\right)$ in the time-integrated sampler strategy was 11.94 (Conceição) and $13.21 \mu \mathrm{m}$ (Guaporé); and in the strategy of sampling by rainfall events the $d_{50}$ was 5.13 (07/20/2011) and $6.59(07 / 21 / 2011)$ for Conceição and Guaporé catchments, respectively. The granulometric analysis showed two important aspects: the differences between the catchments are not sufficient to explain the differences in the turbidity signal recorded on the calibration charts, and the rainfall event sampling exhibit $\mathrm{d}_{50}$ significantly lower, indicating that the sampler is not completely effective in retaining fine sediments. It is expected that in this case, a mathematical relation curve for rainfall event samples would have smaller inclination angle, since particles of larger size compared to smaller particles (time integrated sampler $\mathrm{x}$ rainfall event sampling, and samples from the Guaporé $\mathrm{x}$ Conceição) in a same concentration generate a smaller backscatter (Figure 3) (Merten et al., 2014).

The amplitude of SSC was small in the weekly sampling (Figure 2C). The maximum SSC did not exceed $25 \mathrm{mg} \mathrm{L}^{-1}$, except for a sample from the Conceição catchment, with $89 \mathrm{mg} \mathrm{L}^{-1}$. However, there is a high degree of uncertainty for establishing a regression curve when having only one sample at the end of the curve, thus, this data was not presented in the graph (Figure 2C). The results of this timescale is little used, since most sediment yield occurs during flooding when the concentration 


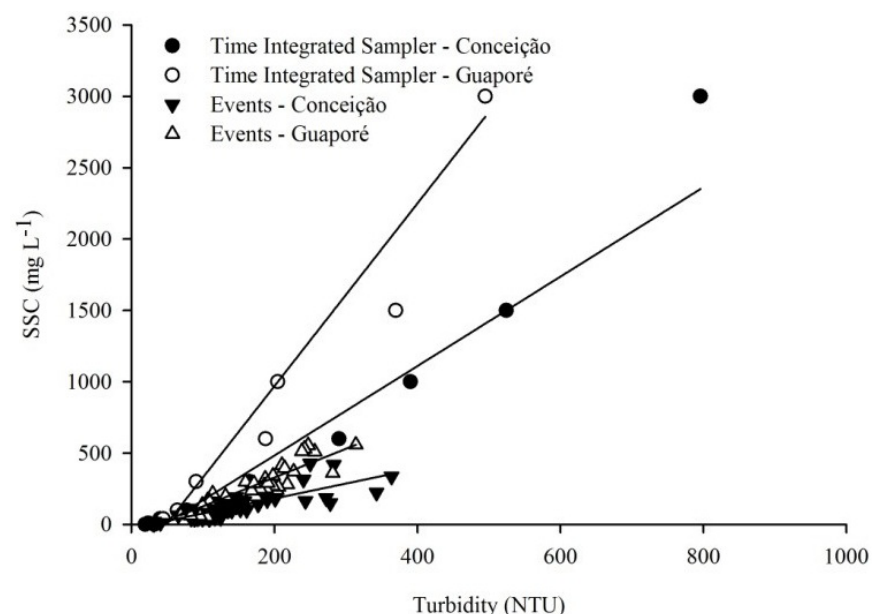

Figure 3. Effect of particle size on suspended sediment concentration (SSC) estimation as a function of turbidity

of sediment is much greater than the magnitude obtained by this scale. These samplings occurred during a period of low rainfall, which may explain the low concentration of suspended sediments, with predominance of dissolved solid $(<0.45 \mu \mathrm{m})$ fractions during this collection period. The range of SSC in daily sampling (Figure 2D) was higher than that in the weekly sampling, but it did not exceed $200 \mathrm{mg} \mathrm{L}^{-1}$, except for one sample from Conceição catchment, which presented SCC of $720 \mathrm{mg} \mathrm{L}^{-1}$, and was also not shown in the graph (Figure 2D).

The data in Figure 2 were organized differently to indicate differences and limitations found in the methods (Figures $4 \mathrm{~A}$ and B). It appears that the calibration with sediments, obtained using the integrated sampler, overestimates SSC compared with the other calibrations, perhaps by the effect of the reduction in the backscatter from coarser sediments in higher proportion. Differences in magnitude of SSC not contemplated by weekly and daily sampling became evident in Figures $4 \mathrm{~A}$ and $\mathrm{B}$.

Finally, Figure 5A describes the SSC sampler calendar for rainfall event, daily and weekly. Four rainfall events were monitored at the Conceição gauge station, where 82 SSC

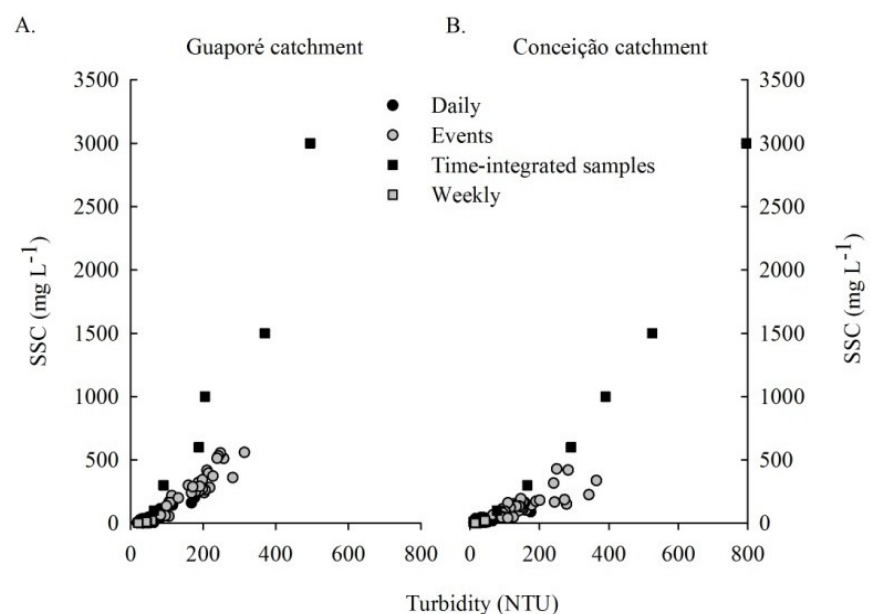

Figure 4. Calibration curves according to sampling strategy for each monitoring station (A) Guaporé catchment and (B) Conceição catchment

samples were collected. In the Guaporé catchment, three rainfall events were monitored and 35 samples were collected. Despite the small number of rainfall events, the collected samples covered a wide range of SSC.

The financial cost of all SSC sampling strategies was also analyzed, such as researchers' daily expenses, transportation (700 km round trip), construction of SSC samplers, and SSC sample analysis (Figure 5B). The daily collections appear to have higher cost, followed by weekly collections and rainfall events. Collections with time-integrated samplers had much lower costs than the other strategies.

Taking into account the costs and benefits of each sampling strategy, the use of daily and weekly sampling is not advantageous. These samplings present high cost and low efficiency, since the amplitude of SSC is not satisfactory to construct a calibration curve, requiring extrapolation to samples with higher turbidity, increasing the chances of error. The costs of sampling rainfall events are high, but the information obtained has great reliability, with a good amplitude of SSC data and sediment characteristics

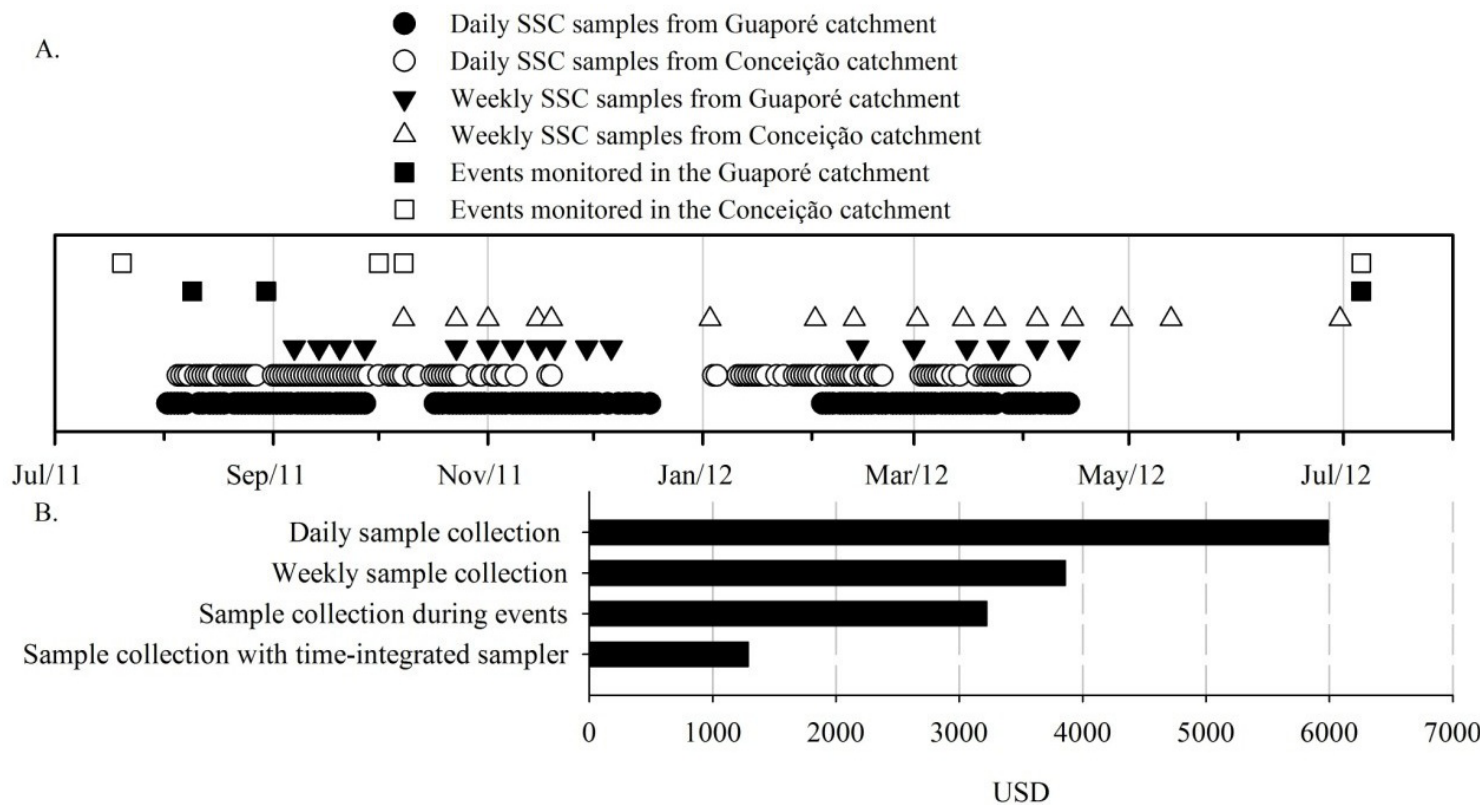

Figure 5. Date of sampling of the different sampling strategies from the Conceição and Guaporé catchments (A), and financial costs of the SSC sampling strategies for the period of one year (B) 
(size, color, mineralogy) resulting in a reliable database (Bouchez et al., 2011; Landers \& Sturm, 2013). Furthermore, according to Lewis (1996), few pairs of data (less than 10) representing the SSC interval should be sufficient to establish a reliable relationship between turbidity and SSC during these rainfall events. The use of a time-integrated sampler presented lower cost but differences in comparison to rainfall event sampling, however, it is a reasonable alternative for obtaining samples for rainfall event calibration in situations of financial constraint and also as a supplementary method. It should be noted that rainfall event monitoring is essential and irreplaceable, both for the turbidimeter calibration and sediment concentration analysis.

\section{Conclusions}

1. The use of turbidity to estimate suspended sediment concentrations is affected by the calibration methodology.

2. Sampling on weekly and daily scales does not provide a range of concentrations representative of sediment transport in the monitored rivers. Moreover, these sampling methods have high costs of monitoring and analysis.

3. The calibration strategy using time-integrated samplers and rainfall events are complementary to each other and enable a correct calibration of turbidimeters and calibration tests regarding the effect of interfering factors (size, color and mineralogy).

\section{Literature Cited}

Bouchez, J.; Gaillardet, J.; France-Lanord, C.; Maurice, L.; Dutra-Maia, P. Grain size control of river suspended sediment geochemistry: Clues from Amazon River depth profiles. Geochemistry, Geophysics, Geosystems, v.12, p.1-24, 2011. https://doi. org/10.1029/2010GC003380

Landers, M. N.; Sturm, T. W. Hysteresis in suspended sediment to turbidity relations due to changing particle size distributions. Water Resources Research, v.49, p.5487-5500, 2013. https://doi. org/10.1002/wrcr.20394

Lenzi, M. A. ; Marchi, L. Suspended sediment load during floods in a small stream of the Dolomites (northeastern Italy). Catena, v.39, p.267-282, 2000. https://doi.org/10.1016/S0341-8162(00)00079-5

Lewis, J. Estimation of suspended sediment flux in streams using continuous turbidity and flow data coupled with laboratory concentrations. In: Gray, J. R.; Douglas, G. (ed.). Workshop on Turbidity and other Sediment Surrogates. April - 30 May 2, Reno: US Geologycal Survey Circular 1250. 2002. 3p.
Lewis, J. Turbidity-controlled suspended sediment sampling for runoff-event load estimation. Water Resources Research, v.32, p.2299-2310, 1996. https://doi.org/10.1029/96WR00991

Merten, G. H.; Capel, P. D.; Minella, J. P. G. Effects of suspended sediment concentration and grain size on three optical turbidity sensors. Journal of Soil and Sediments, v.14, p.1235-1241, 2014. https://doi.org/10.1007/s11368-013-0813-0

Minella, J. P. G.; Merten, G. H.; Reichert, J. M.; Clarke, R. T. Estimating suspended sediment concentrations from turbidity measurement and the calibration problem. Hydrological Processes, v.22, p.18191830, 2008. https://doi.org/10.1002/hyp.6763

Mylvaganam, S.; Jakobsen T. Turbidity sensor for under water applications. Anderaa Instruments Inc Press. 2001. Available in: $<$ https://goo.gl/Bhf8En>. Access in: 5 Jan. 2013.

Pavanelli, D.; Bigi, A. Indirect methods to estimate suspended sediment concentration: Reliability and relationship of turbidity and settleable solids. Biosystems Engineering, v.90, p.75-83, 2005. https://doi.org/10.1016/j.biosystemseng.2004.09.001

Phillips, J. M.; Russell, M. A.; Walling, D. E. Time-integrated sampling of fluvial suspended sediment: A simple methodology for small catchments. Hydrological Processes, v.14, p.2589-2602, 2000. https:// doi.org/10.1002/1099-1085(20001015)14:14\%3C2589::AIDHYP94\%3E3.0.CO;2-D

Rai, A. K.; Kumar, A. Continuous measurement of suspended sediment concentration: Technological advancement and future outlook. Measurement, v.76, p.209-22, 2015. https://doi. org/10.1016/j.measurement.2015.08.013

Shreve, E. A.; Downs, A. C. Quality-assurance plan for the analysis of fluvial sediment by the U. S. Geological Survey Kentucky Water Science Center Sediment Laboratory. Reston, Virginia: U.S. Geological Survey Open-File Report, 2005. 35p.

Slaets, J. I. F.; Schmitter, P.; Hilger, T.; Lamers, M.; Piepho, Hans-Peter; Vien, T. D.; Cadisch, G. A turbidity-based method to continuously monitor sediment, carbon and nitrogen flows in mountainous watersheds. Journal of Hydrology, v.513, p.45-57, 2014. https:// doi.org/10.1016/j.jhydrol.2014.03.034

Slattery, M. C.; Burt, T. P. Particle size characteristics of suspended sediment in hillslope runoff and stream flow. Earth Surface Processes and Landforms, v.22, p.705-719, 1997. https://doi. org/10.1002/(SICI)1096-9837(199708)22:8\%3C705::AIDESP739\%3E3.0.CO;2-6

TOPODATA, Banco de dados geomorfométricos do Brasil. Available in: <http://www.dsr.inpe.br/topodata/acesso.php > Access in: 10 Apr. 2012. 